\begin{tabular}{|c|c|}
\hline \multirow{3}{*}{ 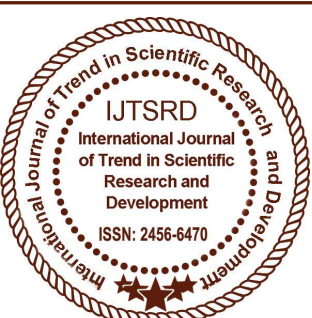 } & $\begin{array}{l}\text { International Journal of Trend in Scientific } \\
\text { Research and Development (IJTSRD) }\end{array}$ \\
\hline & International Open Access Journal \\
\hline & ISSN No: 2456 - 6470 | www.ijtsrd.com | Volume - 2 | Issue - \\
\hline
\end{tabular}

\title{
A Study on Effects and Cultural Impacts of Social Networking Sites Among Students with Special Reference to Coimbatore City
}

\author{
Mrs. B. Janani, Mrs. B. GeethPriya \\ Assistant Professor, Department of Management \\ Rathinam College of Arts \& Science (Autonomous), Coimbatore, India
}

\begin{abstract}
The Social Networking Sites are becoming vital part for the Students. Social networking sites offers students to communicate effectively and also very useful for sharing the information. It allows students to easily their own pages in online network of contacts, also called as 'friends'. Nowadays comparing to other communication methods the Social Networking Sites are faster for sharing the information. This research project work "A Study on Effects and Cultural Impacts of Social Networking Sites among Students with Special Reference to Coimbatore City", analysis the Students preference and attitude towards Social Networking Sites especially Face Book, Twitter, LinkedIn and Others. It also focuses on the impact and effects of Social Networking Sites in Students. The findings from the analysis were discussed in detail and suggestions have been given.
\end{abstract}

Keywords: Social Network, Internet, Communicate

\section{INTRODUCTION}

In the technological world, the internet isthe best method for individuals and families for sharing the information. Social media networks are the best gift of the Internet which has created a new fashion on the internet to communicate word wide faster. The most common social media networks used are Facebook, Twitter, and What's App which are creating and sustaining relationships with others and shares the information on worldwide.

In this "Informational era," social media sites seem to be growing in popularity rapidly, especially among youths. Students mind set made that the Internet is the

only way used to connect with other people, to make new friends, reawaken old friends and to long lost relatives. The appearance of social networking sites (SNSs) makes the process as they are easier to use. The purpose of this study was to examine how social media made an impaction students.

\section{Objectives of The Study}

$\checkmark$ To find the preferable social network site.

$\checkmark$ To find the input of social network sites among students.

To find the preferences of students in social network sites.

$\checkmark$ To identifying social networking usage and the impact on the social interactions and social behaviour.

$\checkmark$ To determine how the students use in social networking in their daily lives.

\section{Limitation of the Study}

$\checkmark$ The sample was restricted to 100 only. So the results cannot be generalized.

Method of data collection was through personal interview and questionnaire so bias becomes a major limitation.

\section{Review of Literature}

1. Williams et al (2008) in "A review of online social networking profiles by adolescents" position that Social networking profiles involve individuals creating and maintaining personal Internet sites allowing authors and other user's topmost content, thus creating a personal network. 
2. Lenhart and Madden (2007) -Proved that in the past five years social networking has gone sky-high from a low position into an event that engages tens of millions of Internet users. The study proposes that online social networking profiles posted by youths contain friendly, honest, and obvious. The study states that fifty-five percent of teenagers use and create online social networking profiles. They speak out that with more than half of teenage Internet users interacting online, the concept of blogging is a outstanding research topic investigating what teenagers are blogging about, how they are socially interacting, and what potential effects these phenomena may have on other dimensions of their lives.

3. Boyd (2007) says that gender appears to influence participation on social network sites. Younger boys are more likely to participate than younger girls but older girls are far more likely to participate than older boys. Older boys are twice as likely to use the sites to flirt and slightly most likely to use the sites to meet new people than girls of their age. Older girls are far more likely to use the sites to connect with friends so easy. They see in person than younger people or boys of their age.

4. Larsen (2009), based on the empirical data, says that both genders seethe acknowledgement they get from having their looks commented on, girls are more preoccupied with what kind of comments they get and whom they come from. In general, it is very important that the comments come from friends and people they know, rather than strangers.

5. Lenhart (2009) the study was conducted for American adults. The study reveals that the usage of adult Internet users who have profile on an online social network site has more importance in the past four years .The study posses a statistical analysis of the usage of various age group of people based on their personal attributes.

\section{Research Methodology}

The data collected from 100 respondents are interpreted and analysis using various tools in order to reach meaningful findings, suggestions and conclusions.

\section{Tools for Analysis}

$>$ Percentage analysis,

$>$ Rank analysis,

$>$ Chi-square test

\section{Finding}

It is in inferred that $42 \%$ of respondents are male and $58 \%$ of respondents are female. It is in inferred that $47 \%$ of respondents age group is 16-20 using and $48 \%$ respondents age group is $21-25$ using and $5 \%$ of respondents age group is 26-30 using and $0 \%$ respondents age group is 31 and above using of the social networking. It is in inferred that $9 \%$ of respondents are school level used of network and $49 \%$ respondents are UG used of network and $42 \%$ of respondents are PG used of network and $0 \%$ respondents of others used of network. It is in inferred that $16 \%$ of respondents are strongly agree about important of networks and $53 \%$ of respondents are Agree about important of networks and $27 \%$ of respondents are Neutral about important of networks and 3\% of respondents are Disagree about important of networks and $1 \%$ of respondents are strongly disagree about important of networks .It is in inferred that $80 \%$ of respondents parents are aware of SNS and $20 \%$ of respondents are not aware of social networks. It is in inferred that $30 \%$ of respondents are strongly agree in learning in schools and colleges and 39\% of respondents are Agree in learning in schools and colleges and $22 \%$ of respondents are Neutral in learning in schools and colleges and $6 \%$ of respondents are Disagree in learning in schools and colleges and $3 \%$ of respondents are strongly disagree in learning in schools and colleges. It is in inferred that $34 \%$ of respondents are having 10-50 number of contacts and $23 \%$ of respondents are having 51-100 number of contacts and $43 \%$ of respondents are more than 100 numbers of contacts.

It is in inferred that $27 \%$ of respondents are developing friends circle and $50 \%$ of respondents are sometimes developing friends circle and $23 \%$ of respondents are never developing friends circle. It is in inferred that 41 of respondents are facing psychological problems and 59\% of respondents are not facing psychological problems. It is in inferred that $40 \%$ of respondents are positively affected by academics because of SNS and $23 \%$ of respondents are negatively affected and $37 \%$ of respondents are having no effect by the SNS

\section{Suggestions}

The social network must create awareness for students among job portals and social welfare activities. The advertisements in every possible media would increase the market share. Most of the respondents face psychological problems so the SNS should have 
Security awareness. LinkedIn have to increase the advertisements among the students.SNS have to increase the privacy policy of their networks.

\section{Conclusion}

The primary objective of this research is to find the growth and control of social networking sites among the college students. Previous researches on social networking sites and its impact on college students in worldwide provided abroad secondary source base for this study. Lot of technologies, adoption of the internet especially for its social uses has seen its highest levels of usage among young college students. The majority college students have had access to the internet and computers for their communication purposes. When Comparing to traditional communication methods, the social networking sites as often a much quicker and more convenient way to interact. But danger and risk are involved in these sites.

\section{Bibliography}

Kotler Philip (1997) "Marketing Management", Prentice Hall of India, New Delhi.

* Kothari C.R(2003) "Research Methodology",.Wishwaprakashan publishers new Delhi.

* Gupta, S.P “ SatisicalMethods”.S. chand\& sons, new Delhi.

- Indian Journal of Marketing June 2007,

Business Todays June 2008,

http://www.managementparadise.com

\begin{tabular}{|c|c|c|c|c|c|c|c|}
\hline Variable & Particulars & $\mathrm{F}$ & $\%$ & Variable & Particulars & $\mathrm{F}$ & $\%$ \\
\hline \multirow[t]{2}{*}{ Gender } & Male & 42 & $42 \%$ & \multirow{4}{*}{$\begin{array}{l}\text { Preferable } \\
\text { way for } \\
\text { accessing } \\
\text { Ournall }\end{array}$} & Laptop & 30 & $30 \%$ \\
\hline & Female & 58 & $58 \%$ & & Smartphone & 57 & $57 \%$ \\
\hline \multirow[t]{4}{*}{ Age } & $16-20$ & $47 a$ & $47 \%$ & & I pod/I pad & 2 & $2 \%$ \\
\hline & $21-25=$ & 48 & $48 \%$ & & Others & 11 & $11 \%$ \\
\hline & $26-30 \bigcirc 9$ & Res & $5 \%$ & \multirow{2}{*}{$\begin{array}{l}\text { Days used } \\
\text { not } \\
\text { ent }\end{array}$} & $\begin{array}{l}\text { Less than a } \\
\text { month }\end{array}$ & 18 & $18 \%$ \\
\hline & 31andabove & 0 & $0 \%$ & & 1-6 month & 25 & $25 \%$ \\
\hline \multirow[t]{4}{*}{ Education } & School level & & & \multirow{2}{*}{170.0} & $\begin{array}{l}7 \text { months to a } \\
\text { year }\end{array}$ & 11 & $11 \%$ \\
\hline & UG & 49 & $49 \%$ & & $\begin{array}{l}\text { More than a } \\
\text { year }\end{array}$ & 46 & $46 \%$ \\
\hline & PG & 42 & $42 \%$ & 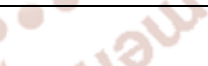 & 0 & & \\
\hline & Others & 0 & $0 \%$ & \multirow{5}{*}{$\begin{array}{c}\text { Attractive } \\
\text { sites }\end{array}$} & Facebook & 45 & $45 \%$ \\
\hline \multirow{2}{*}{$\begin{array}{l}\text { Usage of } \\
\text { network }\end{array}$} & Yes & 95 & $95 \%$ & & Twitter & 4 & $4 \%$ \\
\hline & No & 5 & $5 \%$ & & Whatsapp & 40 & $40 \%$ \\
\hline \multirow{5}{*}{$\begin{array}{c}\text { Frequency } \\
\text { used } \\
\text { network }\end{array}$} & Facebook & 50 & $50 \%$ & & Linkedin & 0 & $0 \%$ \\
\hline & Twitter & 7 & $7 \%$ & & Others & 11 & $11 \%$ \\
\hline & Whatsapp & 40 & $40 \%$ & \multirow[t]{4}{*}{$\begin{array}{l}\text { Reason } \\
\text { for using } \\
\text { social } \\
\text { network }\end{array}$} & $\begin{array}{l}\text { To keep in } \\
\text { touch with } \\
\text { friends and } \\
\text { family }\end{array}$ & 72 & $72 \%$ \\
\hline & Linkedin & 0 & $0 \%$ & & $\begin{array}{l}\text { Solving social } \\
\text { problems }\end{array}$ & 9 & $9 \%$ \\
\hline & Others & 3 & $3 \%$ & & $\begin{array}{l}\text { To use the } \\
\text { leisure time }\end{array}$ & 8 & $8 \%$ \\
\hline Frequently & Everyday & 45 & $45 \%$ & & Other reasons & 11 & $11 \%$ \\
\hline
\end{tabular}


International Journal of Trend in Scientific Research and Development (IJTSRD) ISSN: 2456-6470

\begin{tabular}{|c|c|c|c|c|c|c|c|}
\hline \multirow[t]{3}{*}{ Visited } & Twice a week & 20 & $20 \%$ & & & & \\
\hline & Once a week & 26 & $26 \%$ & \multirow{2}{*}{$\begin{array}{l}\text { Parents } \\
\text { aware }\end{array}$} & Yes & 80 & $80 \%$ \\
\hline & Once a month & 9 & $9 \%$ & & No & 20 & $20 \%$ \\
\hline \multirow{5}{*}{$\begin{array}{c}\text { Time } \\
\text { Spended }\end{array}$} & $<2 \mathrm{hr}$ & 45 & $45 \%$ & \multirow{5}{*}{$\begin{array}{l}\text { Importanc } \\
\text { e of social } \\
\text { networks }\end{array}$} & Strongly agree & 16 & $16 \%$ \\
\hline & 2-4hrs & 20 & $20 \%$ & & Agree & 53 & $53 \%$ \\
\hline & $5-6 h r$ & 26 & $26 \%$ & & neutral & 27 & $27 \%$ \\
\hline & $<6$ hrs & 9 & $9 \%$ & & Disagree & 3 & $3 \%$ \\
\hline & & & & & $\begin{array}{l}\text { Strongly } \\
\text { disagree }\end{array}$ & 1 & $1 \%$ \\
\hline \multirow{5}{*}{$\begin{array}{l}\text { Networking } \\
\text { education }\end{array}$} & Strongly agree & 30 & $30 \%$ & \multirow{2}{*}{$\begin{array}{c}\text { Psycholog } \\
\text { ical } \\
\text { problems }\end{array}$} & Yes & 41 & $41 \%$ \\
\hline & Agree & 39 & $39 \%$ & & No & 59 & $59 \%$ \\
\hline & Neutral & 27 & $22 \%$ & \multirow{2}{*}{$\begin{array}{c}\text { Promotion } \\
\text { of } \\
\text { activities }\end{array}$} & yes & 88 & $88 \%$ \\
\hline & Disagree & 69 & $6 \%$ & & No & 12 & $12 \%$ \\
\hline & Strongly disagr & 3 & $3 \%$ & \multirow{2}{*}{$\begin{array}{l}\text { Keeping } \\
\text { in contact }\end{array}$} & Yes & 88 & $88 \%$ \\
\hline \multirow{5}{*}{$\begin{array}{c}\text { Privacy } \\
\text { policies in } \\
\text { social } \\
\text { networks }\end{array}$} & Strongly agree & 5 & $5 \%$ & & No & 12 & $12 \%$ \\
\hline & Agree & 51 & $51 \%$ & \multirow{5}{*}{$\begin{array}{l}\text { Help in } \\
\text { communic } \\
\text { ating }\end{array}$} & Strongly agree & 12 & $12 \%$ \\
\hline & Neutral & 28 & $28 \%$ & & Agree & 48 & $48 \%$ \\
\hline & Disagree & 12 & $12 \%$ & & Neutral & 31 & $31 \%$ \\
\hline & Strongly disagree & 4 & $4 \%$ & & Disagree & 0 & $0 \%$ \\
\hline \multirow[t]{3}{*}{$\begin{array}{l}\text { Number of } \\
\text { contacts }\end{array}$} & Oct-50 & 34 & $34 \%$ & & $\begin{array}{l}\text { Strongly } \\
\text { disagree }\end{array}$ & 9 & $9 \%$ \\
\hline & $51-100$ & 23 & $23 \%$ & \multirow{3}{*}{$\begin{array}{l}\text { Social } \\
\text { networks } \\
\text { affect the } \\
\text { academics }\end{array}$} & Positively & 40 & $40 \%$ \\
\hline & More than 100 & 43 & $243 \%=6$ & & Negatively & 23 & $23 \%$ \\
\hline \multirow{3}{*}{$\begin{array}{l}\text { Developing } \\
\text { friends circle }\end{array}$} & Yes & 27 & $27 \%$ & & No effect & 37 & $37 \%$ \\
\hline & sometimes & 50 & $50 \%$ & & & & \\
\hline & Never & 23 & $220 /$ & & & & \\
\hline
\end{tabular}

\begin{tabular}{|l|c|c|c|c|}
\hline \begin{tabular}{l} 
Occupation \& $\begin{array}{c}\text { Monthly } \\
\text { Expenditure }\end{array}$ \\
\cline { 2 - 4 }
\end{tabular} & $\begin{array}{c}\text { Chi-Square } \\
\text { Analysis } \\
\text { (Calculated Value) }\end{array}$ & $\begin{array}{c}\text { P value } \\
\text { Expected } \\
\text { Value) }\end{array}$ & $\begin{array}{c}\text { Significant/Not } \\
\text { significant }\end{array}$ & $\begin{array}{c}\text { Hypothesis } \\
\text { Accepted/ } \\
\text { Rejected }\end{array}$ \\
\cline { 2 - 5 } & 2.592 & 16.334 & Not Significant & Accepted \\
\hline
\end{tabular}

